\title{
Epiphytic Populations of Xanthomonas campestris pv. vesicatoria on Pepper: Relationships to Host-Plant Resistance and Exposure to Copper Sprays
}

\author{
Ken Pernezny and Janice Collins, University of Florida, Institute of Food and Agricultural Sciences, Everglades \\ Research and Education Center, P.O. Box 8003, Belle Glade 33430
}

\begin{abstract}
Pernezny, K., and Collins, J. 1997. Epiphytic populations of Xanthomonas campestris pv. vesicatoria on pepper: Relationships to host-plant resistance and exposure to copper sprays. Plant Dis. 81:791-794.

Epiphytic populations of Xanthomonas campestris pv. vesicatoria were monitored on leaves and in buds of resistant and susceptible pepper cultivars over five seasons. Epiphytic populations were higher on the susceptible cultivar Jupiter than on the resistant cultivar Boynton Bell in four of the five seasons. In copper-sprayed plots, populations in buds of Jupiter plants were consistently higher than on leaves. In one test, copper sprays reduced $X$. campestris pv. vesicatoria populations by $99 \%$ on leaves, compared with only a $51 \%$ reduction in buds. In another test on a commercial pepper farm, no differences were found between populations on resistant and susceptible plants spaced as close as $1.2 \mathrm{~m}$. However, combined data on buds for the three cultivars showed populations were higher than those on leaves on three of four sampling dates. These differences were attributed to the heavy use of copper on this farm.
\end{abstract}

It has been known for some time that pathogenic bacteria can survive epiphytically on host plants in the absence of symptoms $(2,7,11,12)$. Populations of epiphytic bacteria have been mostly studied on leaves. However, other plant organs may be important as sites for survival and multiplication of epiphytic bacteria. Buds in particular were shown to harbor significant bacterial populations. Leben $(12,13)$ coined the term "protected positions" to refer to those plant organs, such as buds and flowers, that likely are more moist and receive less ultraviolet light and hence are better environments for bacterial survival and growth.

Bacterial spot, caused by Xanthomonas campestris pv. vesicatoria, is one of the most serious diseases of pepper (Capsicum annuum L.) in Florida (20). Growers routinely apply copper or tank-mix combinations of copper and maneb to reduce disease losses, but chemical control is often less than desirable, especially in warm, rainy weather. Strains of the pathogen with a high degree of tolerance to copper have been implicated in some cases of marginal disease control $(1,15,21,22)$.

Because growers routinely spray pepper fields with copper-maneb tank mixes,

Corresponding author: Ken Pernezny
E-mail: KLP@gnv.ifas.ufl.edu

Florida Agricultural Experiment Station Journal Series R-05448.

Accepted for publication 21 April 1997.

Publication no. D-1997-0603-05R

(C) 1997 The American Phytopathological Society might protected positions harbor higher pathogen populations because they provide safe refuge from contact bactericides? Could poor control with chemical sprays be related, in part, to residual bacterial populations in protected positions that simply escape lethal doses of the copper and maneb?

Host-plant resistance is playing an increasing role in the integrated management of pepper bacterial spot $(5,10,21,23)$. Several cultivars of sweet bell pepper with resistance to all three major races of $X$. campestris pv. vesicatoria found on commercial farms in Florida (21) are now available. Few farmers, however, grow resistant cultivars exclusively. Most farmers typically grow mixed plantings of spotsusceptible bell and specialty peppers (e.g., banana and hot types).

The objectives of this study were to: (i) compare populations of $X$. campestris pv. vesicatoria on leaf surfaces and in protected positions (buds in particular) with and without challenge from copper-maneb sprays, and (ii) compare populations on leaves and in buds for the widely grown bell pepper cultivars Jupiter and Boynton Bell, which are susceptible and resistant to bacterial spot, respectively.

\section{MATERIALS AND METHODS}

Growth of plants. Pepper seeds were germinated in cells in Styrofoam trays containing a commercial potting mix (Metro-Mix 300, W. R. Grace \& Co., Cambridge, MA) and transplanted approximately 4 weeks later into 11.3-liter pots, one plant per pot. One week after transplanting, each pot received $50 \mathrm{~g}$ of a slow-release fertilizer (Osmocote 20-20-
20, Sierra Chemical Co., Milpitas, CA). These pots were maintained in an air-conditioned greenhouse with a maximum temperature of 26 to $29^{\circ} \mathrm{C}$. The house was covered with polypropylene shading, providing 30\% light attenuation, so that a typical light intensity was $755 \mu \mathrm{E} \cdot \mathrm{m}^{-2} \cdot \mathrm{s}^{-1}$.

Inoculum preparation and inoculation. A rifampicin-resistant strain, P437rb, was derived from $\mathrm{P} 437$, a race 1 strain of $X$. campestris pv. vesicatoria recovered from a commercial pepper field in Delray Beach, Florida, in 1990 (21). P437rb was selected as a one-step, spontaneous mutant by plating $0.2 \mathrm{ml}$ of a suspension of $\mathrm{P} 437$ on nutrient agar amended with $0.5 \%$ (wt/vol) glucose (GNA) and $50 \mu \mathrm{g}$ of rifampicin (Sigma Chemical Co., St. Louis, MO) (GNAr). The mutation frequency was $5 / 10^{9}$ cells. Pathogenicity tests on a set of differential cultivars showed P437rb to be phenotypically identical to the P437 wildtype for race and virulence.

Bacteria were grown for $72 \mathrm{~h}$ on GNA. Plates were flooded with sterile buffered saline (PBS) (14), and resultant suspensions were adjusted turbidimetrically to approximately $10^{6} \mathrm{CFU} / \mathrm{ml}$. Four days prior to setting outdoors, suspensions of inoculum were applied to plants with a nonpressurized atomizer until runoff.

Assay of bacterial populations associated with plant organs. Samples of plant organs (usually leaves and buds) were removed with sterile forceps between 0830 and $0930 \mathrm{~h}$. Each plant organ was placed in an individual resealable plastic bag and transported to the laboratory for assay. Symptomless leaves from the upper part of the canopy were selected. Both terminal and axillary buds were used. Populations were determined by placing individual organs (not bulked samples) (6) into sterile $250-\mathrm{ml}$ beakers with $20 \mathrm{ml}$ of sterile washing buffer amended with $0.1 \%$ Bacto peptone (18). Samples were agitated on a rotary shaker for $1 \mathrm{~h}$ at $250 \mathrm{rpm}$.

One milliliter of the washings was removed and serially diluted in sterile PBS, and $0.1 \mathrm{ml}$ of appropriate dilutions was plated on GNAr and spread with a sterile, bent glass rod. Plates were incubated at $28^{\circ} \mathrm{C}$, and colonies were enumerated 3 days later. Populations were expressed as $\log _{10} \mathrm{CFU} / \mathrm{g}$ fresh tissue weight.

Field experiments. A series of experiments was conducted over four seasons on plants grown in pots outdoors on the campus of the Everglades Research and Edu- 


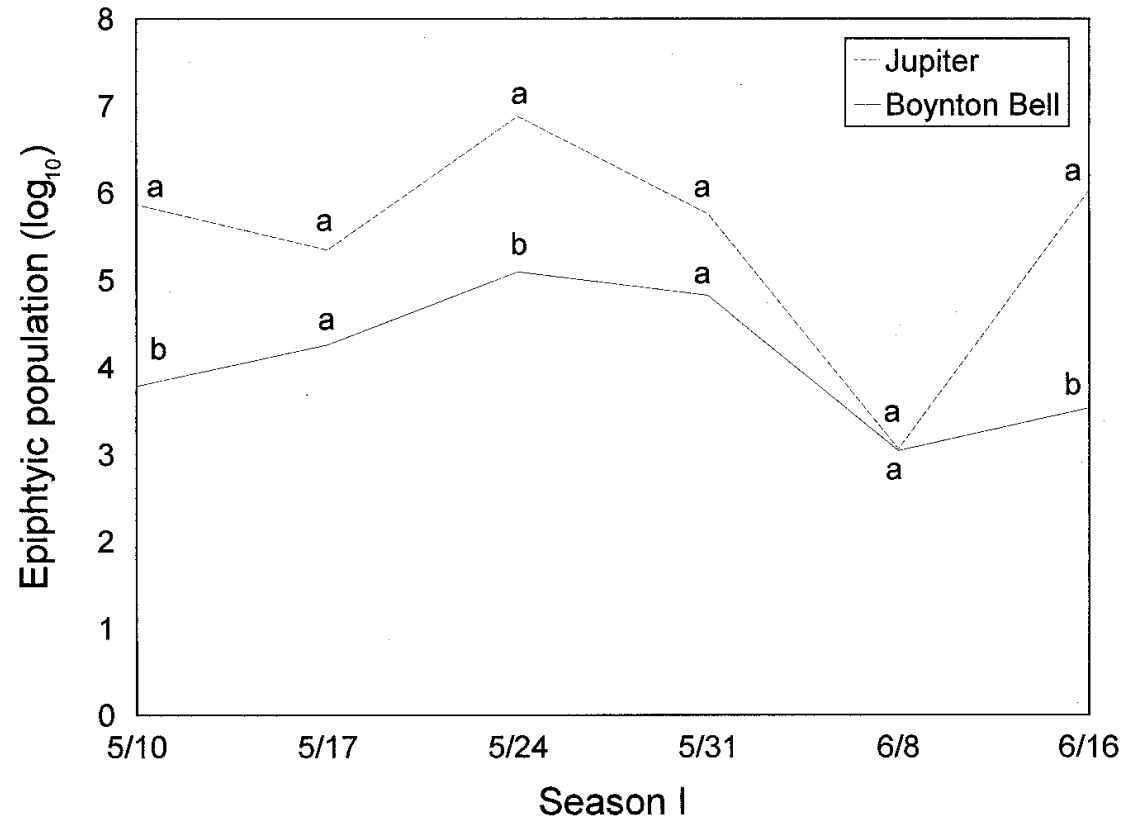

Fig. 1. Epiphytic populations ( $\log _{10} \mathrm{CFU} / \mathrm{g}$ ) over time of Xanthomonas campestris pv. vesicatoria during season I. Only leaves were sampled, and no copper was sprayed. For a given date, means marked with the same letter are not significantly different $(P \leq 0.05$, by ANOVA).

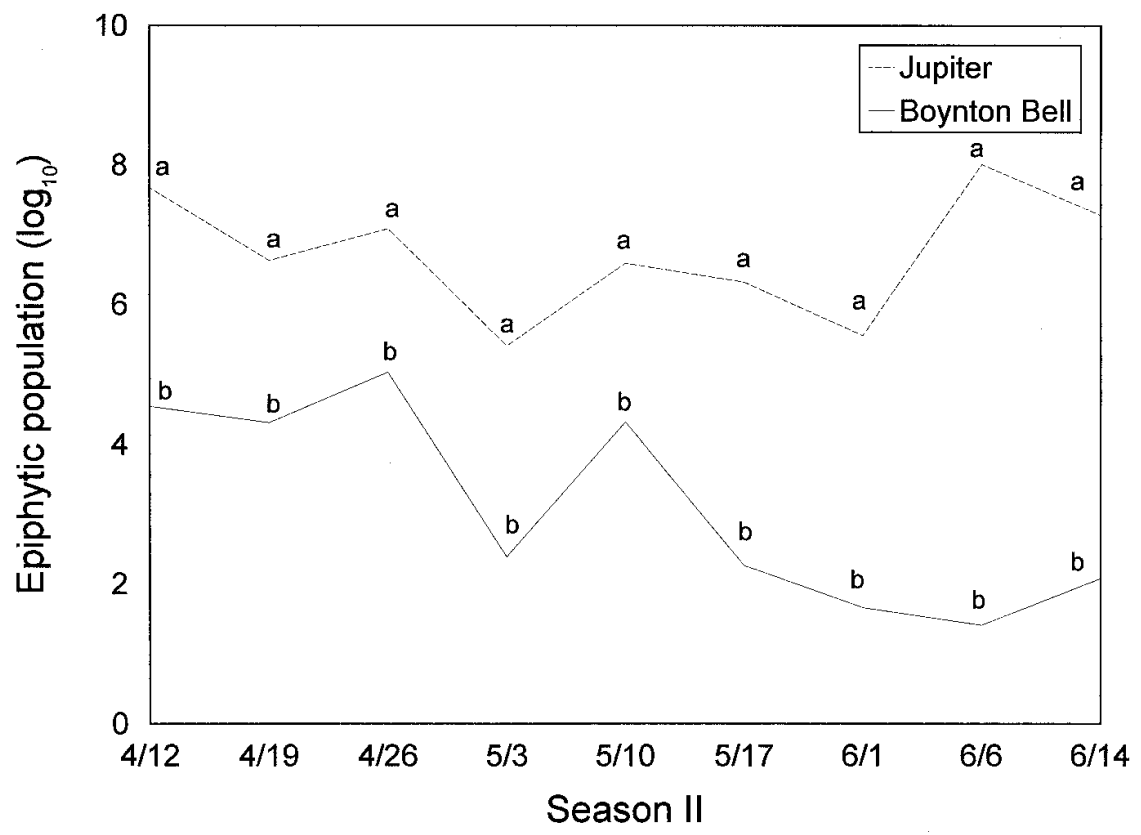

Fig. 2. Epiphytic populations $\left(\log _{10} \mathrm{CFU} / \mathrm{g}\right.$ ) over time of Xanthomonas campestris pv. vesicatoria during season II. No differences were found between buds and leaves for any date (no copper sprayed); therefore, data from plant organs were combined for analysis. For a given date, means marked with the same letter are not significantly different $(P \leq 0.05$, by ANOVA).

cation Center, Belle Glade. Single rows of four pots each of Jupiter and Boynton Bell pepper were arranged in a completely randomized design in locations about the station. Pots in a row were $0.4 \mathrm{~m}$ apart, and there were four replicates of each cultivar. In order to minimize the possible interaction of bacterial populations between the cultivars, test plots were located at least $100 \mathrm{~m}$ apart. Buildings and substantial landscape foliage served as barriers between plots. pv. vesicatoria with leaves and buds was studied. Two five-pot rows of Jupiter or Boynton Bell spaced $1.8 \mathrm{~m}$ apart were randomly assigned to plots established about the station as described. One row of each pair was sprayed weekly with a mixture of copper hydroxide (equivalent of 1.2 $\mathrm{kg}$ of metallic $\mathrm{Cu} / \mathrm{ha})$ and maneb $(1.35 \mathrm{~kg}$ a.i./ha). Applications were made to runoff with a hand-held 4-liter garden sprayer. The other row was sprayed with water only. Two buds and two leaves were removed from plants in copper-treated and control rows each week and assayed for $X$. campestris pv. vesicatoria populations.

An additional comparison of pathogen populations in buds and leaves was made in season $\mathrm{V}$, in a commercial pepper field in Boynton Beach, Florida, under the producer's intense copper-maneb spray schedule. Jupiter, Boynton Bell, and PR89-3 (an advanced breeding line with resistance to race 2 of $X$. campestris pv. vesicatoria only) were arranged in a randomized complete block design in a portion of a larger planting of Boynton Bell. Plots were not inoculated with laboratory cultures. Samples of leaves and buds or other organs that are probable protected positions were removed weekly and assayed on Tween medium B (17).

Data from all experiments were analyzed by ANOVA and Fisher's least significant difference (FLSD) using the Statistical Analysis System (SAS, Cary, NC).

\section{RESULTS}

Epiphytic populations of $X$. campestris pv. vesicatoria were consistently higher on the susceptible cultivar (Jupiter) than on the resistant cultivar (Boynton Bell). In the season I experiment, populations were significantly higher $(P \leq 0.05)$ on three of six sampling dates (Fig. 1). In season II, no differences were noted between populations in buds and leaves, so these data were combined for analysis. In this case, populations on Jupiter were significantly higher on nine of nine sampling dates (Fig. 2).

In seasons III and IV, when copper and maneb were sprayed on plants, buds tended to harbor higher populations of the pathogen (Table 1). In both tests, season-long mean bacterial populations in buds of Jupiter plants were significantly higher than those on leaves. In contrast, populations did not differ significantly between buds and leaves of Jupiter when copper was not used. The relationship between copper and plant organs was less clear with the resistant cultivar Boynton Bell. Populations were significantly higher in buds than on leaves for both copper-sprayed and unsprayed plants in season III. In season IV, no significant differences were found between buds and leaves with or without exposure to copper.

In the season $\mathrm{V}$ test on a commercial farm, no differences in epiphytic populations were found among the three cultivars. 
Table 1. Comparison of epiphytic populations of Xanthomonas campestris pv. vesicatoria associated with buds and leaves of two pepper cultivars sprayed or not sprayed with copper over two seasons ${ }^{\mathrm{y}}$

\begin{tabular}{|c|c|c|c|c|c|c|c|c|}
\hline \multirow[b]{4}{*}{ Organ sampled } & \multicolumn{8}{|c|}{ Season-long mean population $\left(\log _{10} \mathrm{CFU} / \mathrm{g} \text { fresh weight }\right)^{\mathrm{z}}$} \\
\hline & \multicolumn{4}{|c|}{ Season III } & \multicolumn{4}{|c|}{ Season IV } \\
\hline & \multicolumn{2}{|c|}{ Jupiter } & \multicolumn{2}{|c|}{ Boynton Bell } & \multicolumn{2}{|c|}{ Jupiter } & \multicolumn{2}{|c|}{ Boynton Bell } \\
\hline & Sprayed & Not sprayed & Sprayed & Not sprayed & Sprayed & Not sprayed & Sprayed & Not sprayed \\
\hline Buds & $5.55 \mathrm{a}$ & $6.60 \mathrm{a}$ & $3.34 \mathrm{a}$ & $5.42 \mathrm{a}$ & $5.91 \mathrm{a}$ & $5.93 \mathrm{a}$ & $2.97 \mathrm{a}$ & $3.65 \mathrm{a}$ \\
\hline Leaves & $4.69 \mathrm{~b}$ & $6.37 \mathrm{a}$ & $2.17 \mathrm{~b}$ & $4.27 \mathrm{~b}$ & $3.67 \mathrm{~b}$ & $5.50 \mathrm{a}$ & $2.43 \mathrm{a}$ & $3.51 \mathrm{a}$ \\
\hline
\end{tabular}

y Plants sprayed to runoff with tank mix of $1.2 \mathrm{~kg}$ of metallic $\mathrm{Cu} / \mathrm{ha}$ and maneb at $1.35 \mathrm{~kg}$ a.i./ha.

${ }^{\mathrm{z}}$ Means in columns followed by the same letter are not significantly different by Fisher's protected LSD at $P \leq 0.05$.

Table 2. Epiphytic populations of Xanthomonas campestris pv. vesicatoria associated with several plant organs in a replicated field trial on a commercial pepper farm, Boynton Beach, Florida ${ }^{\mathrm{y}}$

\begin{tabular}{llcc}
\hline Date & Organ & $\begin{array}{c}\text { Mean population }\left(\log _{10}\right. \\
\text { CFU/g fresh weight) }\end{array}$ & $\begin{array}{c}\boldsymbol{F} \text { value for organ } \\
\text { comparison }^{\mathbf{z}}\end{array}$ \\
\hline Sept. 30 & Bud & 0.73 & 4.01 \\
Oct. 7 & Leaf & 0.08 & $10.54^{* *}$ \\
& Bud & 2.30 & $5.91^{*}$ \\
Oct. 14 & Leaf & 0.11 & \\
& Bud & 1.26 & 0.01 \\
Oct. 21 & Leaf & 0.11 & \\
& Bud & 3.72 & $6.39^{* *}$ \\
\hline
\end{tabular}

y Four replications of each cultivar were arranged in a randomized complete block design. No differences were found on any dates between populations of $X$. campestris pv. vesicatoria on Jupiter (susceptible), Pr89-3 (resistant to race 2), and Boynton Bell (resistant to races 1, 2, and 3) for any plant organ. Therefore, population estimates for buds and leaves were combined for analysis.

$\mathrm{z} *=$ significant at $P \leq 0.05 ; * *=$ significant at $P \leq 0.01$ by ANOVA.

Therefore, data for organ comparison were analyzed across all cultivars. On three of four sampling dates, populations in buds were significantly higher than those on leaves (Table 2). On another date, flowers were shown to harbor populations equivalent to those in buds.

\section{DISCUSSION}

Protected positions were particularly important for survival and growth of $X$. campestris pv. vesicatoria when pepper was sprayed with copper. In one representative experiment, bacterial populations were reduced $99 \%$ on leaves of Jupiter plants sprayed with copper compared with a $51 \%$ reduction in buds. In contrast, few such differences were found when plants were not sprayed with copper. Leben $(12,13)$ thought that buds provided bacterial phytopathogens with refuge from high levels of ultraviolet light as well as with necessary moisture for growth and reproduction. We suggest that in intensely managed agroecosystems, such as those on Florida pepper farms, reduced exposure to lethal doses of bactericides may be even more important for pathogen survival in buds and similar organs.

A number of reasons have been advanced to explain the relatively poor performance of copper sprays applied for pepper bacterial spot control. These include overwhelming influences of hot, rainy weather $(9,16,18)$ and high incidence of copper tolerance among populations of bacteria $(1,15)$. It also may be that sufficient bacterial cells escape lethal doses of bactericide in protected sites to provide inoculum for sustained disease development.

Generally speaking, resistant cultivar Boynton Bell supported lower epiphytic populations of $X$. campestris pv. vesicatoria than did the susceptible cultivar Jupiter. This was true both for open leaf surfaces and in buds. These observations are similar to those of other workers $(3,18,19)$. Using cultivars that support lower epiphytic populations of $X$. campestris pv. vesicatoria may reduce reservoirs of inoculum for initiation and maintenance of bacterial spot epidemics. In one test (season V), no differences between epiphytic populations on resistant and susceptible cultivars could be found. However, this test was done with plots as close as $1.8 \mathrm{~m}$. It may be that differences were obscured by interplot interference phenomena (8). Fryda and Otta also reported no differences in epiphytic Pseudomonas syringae populations on resistant and susceptible wheat cultivars in a similarly designed experiment (4).

Although populations on the resistant pepper were lower than those on a susceptible pepper, they reached magnitudes of $10^{4}$ cells per $\mathrm{g}$ fresh weight. Even when copper was sprayed, populations in buds of Boynton Bell averaged about 3,000 per g in the season III test (Table 1). Therefore, it is important that vigilance be maintained in production of seed of all pepper culti- vars, including those with resistance to the major races of the bacterial spot pathogen. The demands of produce brokers dictate that Florida growers maintain several pepper types and varieties in contiguous planting in the same season. Many of the specialty peppers (e.g., Jalapeno and Scotch Bonnet) are extremely susceptible to spot (K. Pernezny and J. Collins, unpublished). Symptomless cultivars such as Boynton Bell could harbor populations of $X$. campestris pv. vesicatoria that are potential inoculum sources for nearby susceptible lines.

\section{ACKNOWLEDGMENTS}

We thank Myrine Hewitt, Phillip Garguilo, and Greg Eschinger for their excellent technical assistance; Pepper Research, Inc. and the Florida Bell Pepper Exchange for their financial support of this work; and Dick Amestoy and Ted Winsberg for maintenance of field plots.

\section{LITERATURE CITED}

1. Adaskaveg, J. E., and Hine, R. B. 1985. Copper tolerance and zinc sensitivity of Mexican strains of Xanthomonas campestris pv. vesicatoria, causal agent of bacterial spot of pepper. Plant Dis. 69:993-996.

2. Crosse, J. E. 1959. Bacterial canker of stone fruits. IV. Investigation of a method for measuring the inoculum potential of cherry trees. Ann. Appl. Biol. 47:306-317.

3. Daub, M. E., and Hagedorn, D. J. 1981. Epiphytic populations of Pseudomonas syringae on susceptible and resistant bean lines. Phytopathology 71:547-550.

4. Fryda, S. J., and Otta, J. D. 1978. Epiphytic movement and survival of Pseudomonas syringae on spring wheat. Phytopathology 68:1064-1067.

5. Hibberd, A. M., Bassett, M. J., and Stall, R. E. 1987. Allelism tests of three dominant genes for hypersensitive resistance to bacterial spot of pepper. Phytopathology 77:1304-1307.

6. Hirano, S. S., Nordheim, E. V., Arny, D. C., and Upper, C. D. 1982. Lognormal distribution of epiphytic bacterial populations on leaf surfaces. Appl. Environ. Microbiol. 44:695700 .

7. Hirano, S. S., and Upper, C. D. 1983. Ecology and epidemiology of foliar bacterial pathogens. Annu. Rev. Phytopathol. 29:243-269.

8. James, W. C., Shih, C. S., Hodgson, W. A. and Callbech, L. C. 1976. Representational errors due to interplot interference in field experiments with late blight of potato. Phytopathology 66:695-700.

9. Jones, J. B., and Jones, J. P. 1985. The effect of bactericides, tank mixing times and spray schedule on bacterial leaf spot of tomato. Proc. Fla. State Hortic. Soc. 98:244-247.

10. Kouzik, C. S., and Ritchie, D. F. 1995. Isolation of pepper races 4 and 5 of Xanthomonas 
campestris pv. vesicatoria from diseased peppers in southeastern U. S. fields. Plant Dis. 79:540.

11. Leben, C. 1965. Epiphytic microorganisms in relation to plant disease. Annu. Rev. Phytopathol. 3:209-230

12. Leben, C. 1981. How plant-pathogenic bacteria survive. Plant Dis. 65:633-637.

13. Leben, C. 1988. Relative humidity and the survival of epiphytic bacteria with buds and leaves of cucumber plants. Phytopathology 78:179-185.

14. Leben, C., Daft, G. C., and Schmetthenner, A. F. 1968. Bacterial blight of soybeans: Population levels of Pseudomonas glycinea in relation to symptom development. Phytopathology 58:1143-1146.

15. Marco, G. M., and Stall, R. E. 1983. Control of bacterial spot of pepper initiated by strains of Xanthomonas campestris pv. vesicatoria that differ in sensitivity to copper. Plant Dis. 67:779-781.

16. McCarter, S. M. 1992. Effects of bactericide treatments on bacterial spot severity and yield of different pepper genotypes and on populations of certain insects. Plant Dis. 76:10421045.

17. McGuire, R. G., Jones, J. B., and Sasser, M. 1986. Tween media for the semiselective isolation of Xanthomonas campestris pv. vesicatoria from soil and plant material. Plant Dis. 70:887-891.

18. McGuire, R. G., Jones, J. B., and Scott, J. W. 1991. Epiphytic populations of Xanthomonas campestris pv. vesicatoria on tomato cultigens resistant and susceptible to bacterial spot. Plant Dis. 75:606-609.

19. Mew, T. W., and Kennedy, B. W. 1971. Growth of Pseudomonas glycinea on the surface of soybean leaves. Phytopathology
61:715-716.

20. Pohronezny, K., ed. 1989. The impact of integrated pest management on selected vegetable crops in Florida. Fla. Agric. Exp. Stn. Bull. No. 875.

21. Pohronezny, K., Stall, R. E., Canteros, B. I. Kegley, M., Datnoff, L. E., and Subramanya, R. 1992. Sudden shift in the prevalent race of Xanthomonas campestris pv. vesicatoria in pepper fields in southern Florida. Plant Dis. 75:118-120.

22. Ritchie, D. F., and Dittapongpitch, V. 1991. Copper and streptomycin resistant strains and host-differentiated races of Xanthomonas campestris pv. vesicatoria in North Carolina. Plant Dis. 75:733-736.

23. Sahin, E., and Miller, S. A. 1995. First report of pepper race 6 of Xanthomonas campestris pv. vesicatoria, causal agent of bacterial spot of pepper. Plant Dis. 79:1188. 